\title{
Absurde maar onderkoelde emosie
}

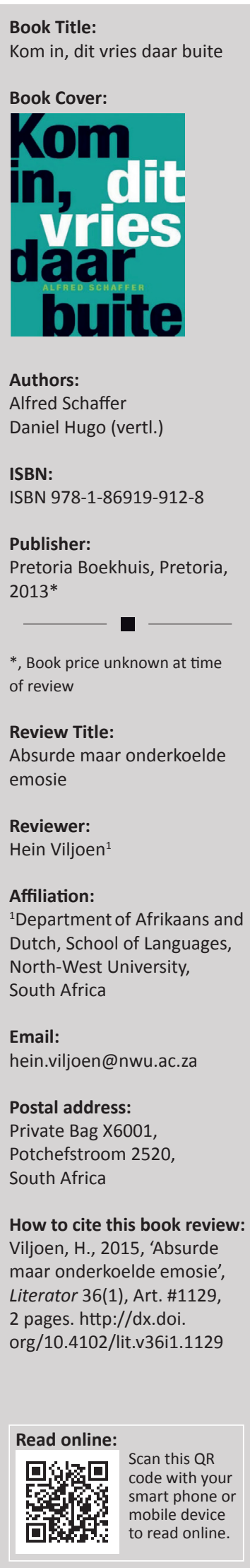

Die verse in hierdie bundel is ' $n$ keuse deur die digter self uit sy vorige bundels, Zijn opkomst in de voorstad (2000), Dwaalgasten (2002), Geen hand voor ogen (2004), Schuim (2006) en Kooi (2008). Daarby het hy drie ongepubliseerde gedigte ingesluit. Daniel Hugo se vertalings van die gedigte is langs die Nederlandse teks afgedruk. Die bundel bied die Afrikaanse lesers dus 'n besondere kennismaking met Schaffer se werk, al ken hulle dit al uit die gedigte van hom wat in Beeld en Die Burger verskyn het.

Schaffer se poësie lyk op die oog af maklik en helder, en asof dit uit doodgewone situasies spruit. Die gedigte word egter uiters enigmaties hoe verder ' $n$ mens lees, omdat dit lyk of hulle willekeurige grepe is uit die verbystromende lewe - so willekeurig gegryp uit die konteks dat hulle heeltemal onbegryplik is. Die situasies waaroor hulle handel, kan byna nie gerekonstrueer word nie, of hoogstens baie voorlopig verstaan word. Die lewe word dus vreemd, absurd.

Eksemplaries hiervan is 'n gedig soos 'Het naleven', waarin die ek-spreker op pad terug is huis toe noudat dit nag geword het en nadink oor die talle ander huise wat hy al gebou het en woorde wat hy vroeër die aand gehoor het. Hy dink aan ander lande waar gewone dinge gebeur, soos dat ' $n$ taxi stilhou by ' $n$ park, oorblyfsels van 'n vuur versprei lê oor ' $n$ strand of iemand verbete by winkelvensters verbyloop op soek na 'n geskenk. Juis die opstapel van hierdie gewone dinge maak die gedig vreemd, en dit word nog vreemder as dit blyk dat die spreker nie weet waarheen hy moet gaan nie en uiteindelik ook nie waarvandaan hy kom nie. Hy, en die leser saam met hom, het beland in ' $n$ situasie waarvan die begin en einde nie meer duidelik is nie.

Die gewone situasie wat in die loop van die gedig al hoe vreemder en absurder word, is as 't ware ' $n$ oppervlakkige teken vir heftige (maar weggesteekte) emosie by die betrokkenes. Dit blyk onder andere uit 'Wat zij doen zonder werkelijk te verdwijnen', wat lyk na die beskrywing - met enkele kwashale - van 'n paartjie se dag by die see. Sy staan in die seewater, hy lê skynbaar en lees op die strand en trotseer ondermeer die bal wat kinders per ongeluk in sy gesig skop. Sy word egter besonder sterk met hitte geassosieer, en die besonder sterk hitte wat die see nie kan afkoel nie omdat hy haar op sy skoot geneem het, skynbaar voor hulle strand toe vertrek het, dien as 'n soort onderkoelde fokuspunt van wat 'n mens seker die gelaaide, erotiese energie tussen hulle moet noem.

Hugo het 'wat zij doen' hier vertaal as 'wat sy doen', terwyl 'wat hulle doen' korrekter sou wees. Moontlik wou hy die klem sterker op haar rol in die situasie laat val. Die titel bly egter raaiselagtig - wat is dit wat hulle doen sonder om te verdwyn? Los sy op in die water? Los hulle albei op in die vreemde situasie? Verloor hulle bestaan omlyning en substansie?

Hierdie gedig illustreer ook dat daar meestal 'n groot gaping tussen die titel en die inhoud van die gedigte is. Die titel lewer dikwels ironies kommentaar op die teks van die gedig, asof 'n enorm afstandelike waarnemer die alledaagse gebeure bekyk, soos in 'Wat wij weten van elkaar' - 'n gedig waarin 'n soort fantasmagoriese situasie opgeroep word waarin sy terugkeer uit die dood en deur 'ons', skynbaar in die verbeelding, afgeloer word. Ten spyte van 'ons' sterkste inbeeldings oor wat sy agter die deure van haar kamer doen, gee sy niks essensieels van haarself prys nie.

Schaffer se verse lyk dikwels na kort dramatiese monoloë waarin 'n figuur iemand anders aanspreek. Die figure is dikwels vasgevang in ' $n$ krisismoment, net voordat ingegrypende dinge gaan gebeur of hulle ingrypende besluite moet neem. Hulle is besig om afskeid te neem of op pad êrens heen in ' $n$ taxi. Dit geld veral vir die dwaalgaste: Superman in ' $n$ parallelle heelal, die leerling, die besoeker in 'Bezoekuur' of 'De sollicitant' - almal figure sonder naam of beroep in nagmerrieagtige situasies waarvan hulle (en ons as lesers) probeer sin maak. 
En dit is moeilik omdat flardes herinnering vermeng word met die hede sodat werklikheid en herinnering, fantasie of droom deurmekaarvloei.

Of ook werklikheid en film, soos in 'Land zo ver je kijken kunt'. Die gedig begin skynbaar in ' $n$ rolprentteater waarin die spreker hom met die held van die prent identifiseer, sigaret in die mondhoek en rewolwer in die regterhand. Agterdog groei in die gedig, maar dit is, volgens die gedig, 'gekneed uit het soort stof waar, in een uiterst verleden, dromen van werden gemaakt' (bl. 42). Ook hier gaan die gedig amper ongemerk oor van werklikheid na fantasie.

Die krisis het dikwels met tyd te doen - 'n stuitpunt of stolpunt in die tyd, ' $n$ besef dat die tyd op die een of ander manier gaan eindig. Die titel 'De situatie tegen sluitingstijd' is tiperend hiervan. In 'Daar horen we engelen zingen' is die koms van die dood onafwendbaar soos die loop van 'n rivier, maar bestaan die hoop tog dat ' $n$ harde kliplaag die loop daarvan sal belemmer.

Die tyd as grens of hinderpaal is ook 'n belangrike tema in 'De tijd kan ons gestolen worden', 'n gedig opgedra aan Lisbé Smuts. Hier probeer die spreker die moment vasvang terwyl die tyding van Lisbé se dood al onderweg was; die oomblikke toe alles nog is soos dit was, maar ook die verdriet daarna omdat hy en sy ook onherroeplik verander het.

Schaffer gee sterk en beslis vorm aan hierdie stolpunte in die tyd in vierreëlige verse waardeur volsinne stroom. Dit is in Afrikaans nie altyd maklik om die tydsduur (duratief) van die Nederlands weer te gee nie. Vergelyk byvoorbeeld 'Er stond iets te gebeuren' wat juis die stolling van die tyd verloor as Hugo dit vertaal met 'Moet iets gebeur?' (bl. 42). Hugo se vertalings is redelik letterlik, wat soms meebring dat hy minder raak Afrikaanse woorde of uitdrukkings gebruik. Die vlak deel van die swembad is tog die vlakkant (bl. 25). 'Ik wil zien hoe mijn geschenken je staan' sal ek eerder vertaal as 'Ek wil sien hoe jy lyk met my geskenke aan' en nie as 'hoe my geskenke jou pas' (bl. 27) nie.

Soms het Hugo wel skitterende oplossings gevind, soos om 'Maar laten we elkaar in vredesnaam niet tutoyeren' te vertaal met 'Maar laat ons mekaar in vredesnaam nie jy en jou nie' (bl. 65), wat ook perfek inpas in die toonaard van die gedig.

Dit bly ' $n$ uitdaging om Schaffer se enigmatiese gedigte te vertaal, en dat Hugo in ' $\mathrm{n}$ groot mate daarin slaag om die toonaard van die gedigte in Afrikaans om te sit, maak hierdie versameling ' $n$ belangrike bundel - te meer omdat dit ook die subtiliteit van Schaffer se poësie onder die aandag bring.

\section{Literatuurverwysings}

Schaffer, A., 2000, Zijn opkomst in de voorstad, Thomas Rap, Amsterdam.

Schaffer, A., 2002, Dwaalgasten, Thomas Rap, Amsterdam.

Schaffer, A., 2004, Geen hand voor ogen, De Bezige Bij, Amsterdam.

Schaffer, A., 2006, Schuim, De Bezige Bij, Amsterdam.

Schaffer, A., 2008, Kooi, De Bezige Bij, Amsterdam. 